\title{
Genetic Variability, Character Association and Path Analysis in Boro Rice (Oryza sativa L.) Germplasm from Bangladesh
}

\author{
M Z Islam ${ }^{1}$, T Chakrabarty ${ }^{1}$, N Akter ${ }^{1}$, E S M H Rashid ${ }^{1}$, M Khalequzzaman ${ }^{1}$ \\ and M A Z Chowdhury ${ }^{2}$
}

\begin{abstract}
The success of varietal development programmme largely depends on the nature and magnitude of genetic variability, heritability and characters association of the crop. The objective of the present study was to estimate the extent of genetic variability and relation between yield and related characters of rice. Forty Boro rice germplasm were evaluated in a randomised complete block design with three replications. Analysis of variance indicated significant differences among the genotypes for 14 quantitative characters. The presence of slightly higher phenotypic coefficient of variation than genotypic coefficient of variation indicated the negligible influence of environment on the expression of yield and its component traits. Leaf length, days to flowering, days to maturity and 1000 grain weight showed highly positive significant correlation present with yield hill-1. High heritability had been observed for yield contributing traits during the study, suggested that these traits would respond to selection owing to their high genetic variability and transmissibility. Therefore, a thorough understanding of the inheritance of traits, their heritability and relationship with other important characteristics is important for the choice of breeding and selection methods for crop improvement.
\end{abstract}

Key words: Variability, heritability, correlation coefficients, path analysis, rice (Oryza sativa L.)

\section{INTRODUCTION}

There are thousands of rice varieties, genotypes and landraces which differ from each other with respect to plant types of various nature and grain characteristics such as, grain size, texture, glutinous or non glutinous, aromatic or non aromatic and quality (Islam et al., 2016). Asian and African farmers selected different types of rice to suit local condition and needs (Singh et al., 2000). It continues to be the major source of livelihood, especially in the rural areas and the main staple food for more than half of the world's population.

Rice plays a vital role in Bangladesh's economy and agriculture, accounting for nearly $18 \%$ of the gross domestic product (BBS, 2017). About $76 \%$ of the total cropped land is covered by rice and more than $66 \%$ of the total agriculture labour force is employed in rice production, processing, marketing and distribution. It provides about $62 \%$ of the calorie and $46 \%$ of the protein in the average daily diet for the people of the country (HIES, 2010). Bangladesh is the fourth largest producer and consumer of rice in the world with an annual production of 34.71 million metric tons (BBS, 2017). In Bangladesh, three major rice seasons namely Aus, T. Aman and Boro constitute $100 \%$ of total rice production and grow in three overlapping seasons. Among three growing seasons, Boro rice (irrigated rice) occupied the second highest, which is about $41.94 \%$ of total rice land and contributes $54.57 \%$ of the total rice production (Anonymous, 2017). Although 
Bangladesh is now on the verge of attaining self sufficiency in cereal production, there is still a gap between the production and demand. Again, population in the country is increasing rapidly and land under rice cultivation is decreasing day by day due to rapid urbanization and development of infrastructures. If this situation continues we have to face hard challenge to feed the numerous hungry mouths of the future. So, we should think of expanding rice production per unit area and increasing productivity or both.

Grain yield is the major factor in determining the improvement of a cereal crop. For efficient utilization of genetic stock in crop improvement, information of mutual association between yield and yield components is necessary. Grain yield in rice is a quantitative character, which is influenced by a number of yield contributing characters. So, the selection for desirable types should not only be based on yield, but other yield components should also be considered. The success of a breeding programme depends largely upon the amount of genetic variability present in the population and the extent to which the desirable traits are heritable. Moreover, knowledge of correlation between yield and its contributing agro-morphological traits are basic requirement to find out guidelines for plant selection. In rice, large amount of genetic variability has been reported (Khatun et al., 2015; Ahmed et al., 2015; Islam et al., 2017; Akter et al., 2018; Islam et al., 2018) which indicates the potential for genetic improvement. Partitioning of total correlation into direct and indirect effect by path analysis helps in making the selection more meaningful way. The present investigation was, therefore, undertaken to estimate genetic variability, associations among desired traits and their direct and indirect contributions toward grain yield in rice.
MATERIALS AND METHODS

\section{Materials, design and intercultural operations}

Forty Boro rice germplasm (Table 1) were collected from the Genebank of Bangladesh Rice Research Institute (BRRI) in which 11 were newly collected from the different districts of Bangladesh. The experiment was conducted at BRRI HQ farm, Gazipur during Boro season 2016-17. The trial was conducted in a randomized complete block design with three replications. Forty-day-old seedlings grown in wet seed bed were transplanted using single seedling hill-1 in $2.4 \mathrm{~m}^{2}$ plot following $20 \mathrm{~cm}$ and $20 \mathrm{~cm}$ space between rows and plants respectively. Fertilizers were applied @ 80:60:40:12 kg N, P, K and S per hectare. All the fertilizers except $\mathrm{N}$ were applied at final land preparation. Nitrogen was applied as urea in three equal splits at 15 days after transplanting (DAT), at 35 DAT and just before flowering. Intercultural operations and pest control measures were done as and when necessary.

Data were collected from the randomly selected ten plants in each replication for leaf length $(\mathrm{cm})$, leaf width $(\mathrm{cm})$, number of effective tiller, panicle length $(\mathrm{cm})$, plant height $(\mathrm{cm})$, days to flowering, days to maturity, filled grains per panicle, 1000 grain weight (TGW) $(\mathrm{g})$, grain length $(\mathrm{mm})$, grain breadth $(\mathrm{mm})$, decorticated grain length $(\mathrm{mm})$, decorticated grain breadth (mm), decorticated grain length breadth ratio and yield hill-1 $(\mathrm{g})$.

\section{Statistical analysis}

The analysis of variance was done using Statistix 10 software. The calculation of mean, range and standard deviation (SD) was also done for each character. The mean sum of square was estimated for the calculation of genotypic and phenotypic variances (Johnson et al., 1955). Genotypic and phenotypic coefficients of variation were estimated by the suggested formula (Burton, 1952). The 
broad sense heritability and genetic advance was estimated by the suggested formula (Johnson et al., 1955 and Lush, 1949). Genetic advance in percentage of mean was calculated for different characters by the given formula (Comstock et al., 1952). Phenotypic and genotypic correlations were calculated by using the suggested formula
(Falconer, 1964). Path coefficient analysis was estimated according to method modified by Dewey and Lu (1959). After calculating the direct and indirect effect of different traits, the co-efficient of determination $\left(\mathrm{R}^{2}\right)$ and residual effect $(\mathrm{U})$ were calculated using the formula suggested by Singh and Choudhury (1985).

Table 1. Information on local name, place of collection and season of the Boro rice germplasm.

\begin{tabular}{|c|c|c|c|c|c|}
\hline Code no. & Local name & Acc. no. & Upazila & District & Season \\
\hline G1. & Begun Bichi & 7358 & Sadar & Manikganj & Boro \\
\hline G2. & Nerica-10 & 7361 & Sadar & Jessore & Boro \\
\hline G3. & Jhora Dhan-1 & 7362 & Monirampur & Dinajpur & Boro \\
\hline G4. & Jhora Dhan-2 & 7363 & Sadar & Dinajpur & Boro \\
\hline G5. & Minikit & 7364 & Sadar & Rangpur & Boro \\
\hline G6. & Sada Jamai Babu & 7368 & Sadar & Satkhira & Boro \\
\hline G7. & Kajollata & 7369 & Tala & Satkhira & Boro \\
\hline G8. & Super Miniket & 7370 & Tala & Satkhira & Boro \\
\hline G9. & Ponchog & 7372 & Tala & Khulna & Boro \\
\hline G10. & Chandrone & 7373 & Dumuria & Jamalpur & Boro \\
\hline G11. & Khaily & 7374 & Sadar & Jamalpur & Boro \\
\hline G12. & Lal Swarna & 7375 & Sadar & Nilphamari & Boro \\
\hline G13. & Pajam Boro & 7376 & Sadar & Naranganj & Boro \\
\hline G14. & Sunwala Dhan & 7378 & Sadar & Naranganj & Boro \\
\hline G15. & Sada Boro & 7379 & Sadar & Naranganj & Boro \\
\hline G16. & Jirasail & 7381 & Sadar & Cumilla & Boro \\
\hline G17. & Tepul & 7382 & Sadar & Patuakhali & Boro \\
\hline G18. & Shakti-R & 7386 & Sadar & Gazipur & Boro \\
\hline G19. & Khato Vojon & 7656 & Sadar & Pirojpur & Boro \\
\hline G20. & Kali Boro-1 & 7657 & Sadar & Pirojpur & Boro \\
\hline G21. & Lal Vojon & 7658 & Sadar & Pirojpur & Boro \\
\hline G22. & Black Vojon & 7659 & Sadar & Pirojpur & Boro \\
\hline G23. & Sada Vojon & 7660 & Sadar & Pirojpur & Boro \\
\hline G24. & Khami Dhan & 7661 & Sadar & Pirojpur & Boro \\
\hline G25. & Abdul Hai & 7662 & Sadar & Barguna & Boro \\
\hline G26. & Kalo Boro & 7663 & Sadar & Barguna & Boro \\
\hline G27. & Aynasail & 7665 & Sadar & Sylhet & Boro \\
\hline G28. & Ayla binni & 7666 & Sadar & Habigonj & Boro \\
\hline G29. & Kali Boro-2 & $\mathrm{NC}^{*}$ & Sadar & Tangail & Boro \\
\hline G30. & Atasail & $N C^{*}$ & Sadar & Tangail & Boro \\
\hline G31. & Kajallata & $N C^{*}$ & Sadar & Jashore & Boro \\
\hline G32. & Suballata & $N C^{*}$ & Sadar & Jashore & Boro \\
\hline G33. & Unknown-1 & $\mathrm{NC}^{*}$ & Sadar & Jashore & Boro \\
\hline G34. & Suballata & $\mathrm{NC}^{*}$ & Sadar & Jashore & Boro \\
\hline G35. & Super miniket & $N C^{*}$ & Sadar & Jashore & Boro \\
\hline G36. & K-1 & $\mathrm{NC}^{*}$ & Sadar & Dinajpur & Boro \\
\hline G37. & Sada Boro & $\mathrm{NC}^{*}$ & Sadar & Rajshahi & Boro \\
\hline G38. & Tulsi Boro & $\mathrm{NC}^{*}$ & Sadar & Rajshahi & Boro \\
\hline G39. & Unknown-2 & $\mathrm{NC}^{*}$ & Sadar & Rajshahi & Boro \\
\hline G40. & Dhali Boro & $N C^{*}$ & Sadar & Tangail & Boro \\
\hline
\end{tabular}

${ }^{*} \mathrm{NC}=\mathrm{New}$ collection. 


\section{RESULTS AND DISCUSSION}

After analyzing the mean performance of these germplasm, it was found that 20 germplasm for leaf length, 20 for leaf width, 13 for effective tiller, 23 for panicle length, 19 for plant height, 16 for days to flowering, 17 for days to maturity, 19 for filled grain per panicle, 20 for 1000 grain weight, 17 for grain length, 18 for grain breadth, 18 for decorticated grain length, 17 for decorticated grain breadth, 17 for decorticated grain length breadth ratio, 20 for yield hill-1 were out performed over their grand mean (GM) values, respectively (Table 2). According to the mean performance, of the studied germplasm, it is observed that few of them can be selected for their better performance, such as G28 for the highest yield hill-1, G15 and G16 for similar higher yield, G20 for the highest TGW, G11 for filled grains per panicle, G39 for the shortest days to maturity, G17 for the longest panicle length and G2 for the longest grain length.

Table 3 presents the estimation of genotypic and phenotypic coefficients of variation, heritability, genetic advance and genetic advance as percent of mean. Wide genotypic and phenotypic differences were present for all the traits except leaf width, grain breadth and decorticated grain length breadth ratio. This result presents that there is less/no environmental influence on these traits. High magnitude of genotypic coefficient of variation indicated the presence of substantial amount of genetic variability in the population and there was little influence of the environment on the expression of the studied characters. Phenotypic coefficients of variation were little higher than the genotypic coefficient of variation for all characters as it was expected. This is due to less environmental influences during the expression of the traits. The environmental influence would be added on PCV that made the value higher. Similar findings were also reported by Akter et al. (2018). The coefficients of genotypic and phenotypic variability were comparatively high for filled grains panicle ${ }^{-1}$ (30.32 and 30.60), effective tillers plant ${ }^{-1}$ (27.23 and 29.06) and yield hill-1 (27.25 and 27.31). These results were in agreement with the findings by Mishra and Verma (2002) and Gour et al. (2017).

Heritability of a trait is an index of transmission of characters from parents to its progeny. The estimates of heritability help the plant breeder in selection of elite genotypes from diverse genetic population, hence prior knowledge about the heritability of the traits is a prerequisite for the selection programme (Singh et al., 2011). Broad sense heritability explains both fixable (additive) and non-fixable (dominant and epistatic) variances, which helps in estimating the inheritance of a character (Nirmaladevi et al., 2015). On the basis of heritability, the traits can be classified into three categories viz. highly heritable $(>70 \%)$, medium heritable $(50-70 \%)$ and low $(<50 \%)$ (Burton, 1952). The magnitude of the estimated broad sense heritability in this study ranged from 86.52 for leaf width to 96.70 for days to flowering. Leaf length, panicle length, plant height, days to flowering, days to maturity, filled grain per panicle, 1000 grain weight, grain length, grain breadth, decorticated grain length and decorticated grain length-breadth ratio were highly heritable, all with an estimated $\mathrm{H}^{2}>90.00$, whereas other characters showed relatively low heritability. High heritability coupled with high genetic advance as percent of mean was observed in leaf length (96.12, 33.87), number of effective tiller $(87.81,40.32)$, filled grains per panicle (95.17, 36.47), 1000 grain weight $(90.56,35.72)$ and decorticated grain length breadth ratio $(91.17,31.49)$ indicating the role of additive gene expression of these traits and have better scope for improvement of these traits through direct selection. Similar results were reported by Gour et al. (2017) and Lakshmi et al. (2017). 
Table 2. Mean performance of 40 Boro rice germplasm.

\begin{tabular}{|c|c|c|c|c|c|c|c|c|c|c|c|c|c|c|c|}
\hline $\begin{array}{l}\dot{8} \\
\stackrel{0}{0} \\
\dot{0}\end{array}$ & 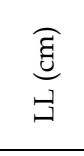 & 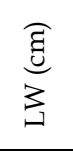 & 㫐 & 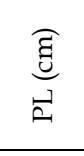 & 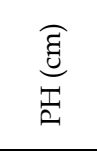 & 岶 & $\sum_{\Delta}$ & 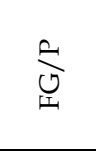 & $\begin{array}{c}30 \\
3 \\
0 \\
0\end{array}$ & $\underbrace{\overparen{\Xi ્ \Xi ~}}_{\mathcal{U}}$ & 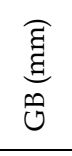 & 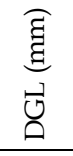 & 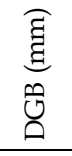 & 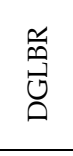 & 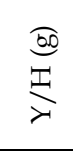 \\
\hline G1 & 42.40 & 1.04 & 12 & 24.93 & 123.00 & 116 & 142 & 189 & 11.60 & 5.25 & 2.95 & 3.55 & 2.57 & 1.38 & 15.29 \\
\hline G2 & 40.27 & 1.43 & 9 & 24.00 & 89.07 & 118 & 144 & 146 & 29.95 & 9.78 & 3.03 & 6.78 & 2.59 & 2.62 & 23.27 \\
\hline G3 & 38.80 & 1.14 & 11 & 20.53 & 78.03 & 118 & 144 & 76 & 20.20 & 7.55 & 2.81 & 5.40 & 2.54 & 2.12 & 13.54 \\
\hline G4 & 45.33 & 0.95 & 15 & 21.40 & 84.07 & 118 & 143 & 10 & 20.40 & 7.95 & 2.79 & 5.35 & 2.47 & 2.17 & 13.81 \\
\hline G5 & 37.80 & 1.00 & 11 & 24.00 & 95.43 & 115 & 141 & 177 & 23.33 & 9.22 & 2.17 & 6.87 & 1.92 & 3.58 & 23.40 \\
\hline G6 & 28.93 & 0.75 & 10 & 24.93 & 83.23 & 110 & 137 & 135 & 22.60 & 9.40 & 2.54 & 6.73 & 2.32 & 2.89 & 22.56 \\
\hline G7 & 36.07 & 0.90 & 9 & 26.47 & 96.00 & 110 & 136 & 147 & 22.20 & 9.35 & 2.80 & 6.61 & 2.34 & 2.83 & 22.37 \\
\hline G8 & 40.80 & 1.00 & 10 & 23.47 & 88.80 & 110 & 137 & 152 & 18.90 & 9.59 & 2.29 & 6.72 & 2.01 & 3.35 & 20.80 \\
\hline G9 & 38.53 & 1.24 & 10 & 23.47 & 93.23 & 120 & 146 & 161 & 29.00 & 9.48 & 3.03 & 7.10 & 2.65 & 2.67 & 23.85 \\
\hline G10 & 24.53 & 0.65 & 20 & 20.00 & 104.00 & 105 & 132 & 66 & 20.07 & 8.19 & 3.20 & 5.80 & 2.71 & 2.14 & 11.30 \\
\hline G11 & 34.20 & 1.10 & 10 & 25.00 & 96.67 & 136 & 162 & 204 & 22.70 & 7.70 & 2.88 & 5.59 & 2.63 & 2.13 & 23.91 \\
\hline G12 & 42.47 & 1.20 & 13 & 25.07 & 102.50 & 124 & 149 & 115 & 16.60 & 7.53 & 2.61 & 5.16 & 2.62 & 2.03 & 21.89 \\
\hline G13 & 44.13 & 1.25 & 12 & 23.53 & 117.80 & 118 & 144 & 124 & 17.80 & 7.62 & 2.73 & 5.23 & 2.39 & 2.18 & 22.27 \\
\hline G14 & 41.93 & 1.15 & 16 & 18.27 & 81.13 & 124 & 150 & 103 & 21.70 & 7.49 & 2.66 & 5.31 & 2.30 & 2.31 & 24.79 \\
\hline G15 & 44.40 & 1.23 & 12 & 25.00 & 92.20 & 118 & 145 & 150 & 22.50 & 8.28 & 2.57 & 5.78 & 2.25 & 2.57 & 25.42 \\
\hline G16 & 35.93 & 1.15 & 8 & 23.53 & 88.27 & 115 & 141 & 133 & 18.12 & 9.05 & 2.30 & 6.38 & 2.05 & 3.11 & 25.36 \\
\hline G17 & 37.53 & 1.05 & 11 & 31.47 & 95.80 & 139 & 166 & 88 & 26.40 & 8.49 & 3.26 & 6.18 & 2.81 & 2.19 & 23.47 \\
\hline G18 & 45.87 & 1.09 & 11 & 23.47 & 86.53 & 130 & 155 & 95 & 28.75 & 8.87 & 3.09 & 5.78 & 2.33 & 2.48 & 23.96 \\
\hline G19 & 35.60 & 1.04 & 13 & 21.40 & 74.93 & 130 & 157 & 87 & 28.20 & 8.22 & 3.20 & 5.82 & 2.84 & 2.05 & 22.69 \\
\hline G20 & 42.20 & 1.19 & 11 & 24.47 & 120.13 & 124 & 150 & 146 & 30.72 & 7.86 & 3.48 & 5.56 & 2.90 & 1.92 & 24.21 \\
\hline G21 & 33.33 & 1.14 & 11 & 21.93 & 63.73 & 116 & 142 & 119 & 26.10 & 8.07 & 3.31 & 5.50 & 2.77 & 1.99 & 20.38 \\
\hline G22 & 36.80 & 1.09 & 12 & 21.00 & 111.63 & 104 & 133 & 45 & 23.80 & 8.28 & 2.76 & 5.93 & 2.52 & 2.35 & 18.82 \\
\hline $\mathrm{G} 23$ & 46.80 & 1.25 & 9 & 27.60 & 86.33 & 117 & 143 & 115 & 25.00 & 8.10 & 3.21 & 5.70 & 2.86 & 1.99 & 21.47 \\
\hline G24 & 44.80 & 1.24 & 10 & 26.87 & 97.33 & 116 & 142 & 159 & 14.50 & 6.18 & 2.64 & 4.19 & 2.32 & 1.81 & 15.25 \\
\hline G25 & 72.27 & 1.03 & 10 & 23.40 & 111.53 & 131 & 157 & 114 & 25.30 & 8.23 & 3.06 & 5.33 & 2.53 & 2.12 & 24.10 \\
\hline G26 & 39.40 & 0.95 & 13 & 20.47 & 90.70 & 114 & 144 & 94 & 28.00 & 8.22 & 3.16 & 5.99 & 2.67 & 2.24 & 23.78 \\
\hline G27 & 36.67 & 0.99 & 10 & 26.33 & 94.07 & 127 & 152 & 150 & 21.40 & 8.57 & 2.66 & 6.16 & 2.21 & 2.79 & 17.53 \\
\hline G28 & 40.93 & 1.04 & 9 & 29.00 & 89.60 & 115 & 141 & 150 & 19.90 & 8.14 & 2.52 & 5.80 & 2.32 & 2.51 & 26.43 \\
\hline G29 & 29.20 & 0.81 & 25 & 19.40 & 112.40 & 105 & 132 & 147 & 16.85 & 8.85 & 2.63 & 6.34 & 2.19 & 2.89 & 8.663 \\
\hline G30 & 45.60 & 0.97 & 10 & 26.40 & 116.60 & 116 & 142 & 95 & 20.50 & 7.91 & 2.68 & 5.39 & 2.41 & 2.23 & 16.05 \\
\hline G31 & 28.26 & 0.94 & 13 & 21.47 & 83.10 & 114 & 140 & 114 & 17.30 & 8.23 & 2.30 & 5.96 & 2.01 & 2.97 & 16.16 \\
\hline G32 & 27.40 & 0.82 & 9 & 21.40 & 95.00 & 115 & 141 & 180 & 10.60 & 8.06 & 2.18 & 5.69 & 1.95 & 2.93 & 12.33 \\
\hline G33 & 32.00 & 1.05 & 11 & 22.40 & 75.07 & 113 & 140 & 102 & 23.30 & 9.63 & 2.34 & 6.54 & 2.15 & 3.05 & 11.26 \\
\hline G34 & 31.47 & 0.95 & 7 & 20.87 & 75.13 & 116 & 142 & 149 & 14.30 & 6.62 & 2.75 & 4.36 & 2.42 & 1.80 & 17.01 \\
\hline G35 & 38.40 & 1.09 & 9 & 25.00 & 78.00 & 116 & 142 & 122 & 16.53 & 9.05 & 2.24 & 6.45 & 2.04 & 3.16 & 15.49 \\
\hline G36 & 34.47 & 1.09 & 12 & 25.40 & 92.27 & 116 & 141 & 134 & 16.50 & 9.03 & 2.07 & 6.54 & 1.83 & 3.57 & 16.89 \\
\hline G37 & 29.67 & 1.03 & 11 & 20.40 & 101.13 & 102 & 130 & 67 & 20.40 & 7.41 & 2.79 & 5.55 & 2.40 & 2.31 & 15.87 \\
\hline G38 & 22.00 & 0.72 & 13 & 19.13 & 98.00 & 105 & 132 & 66 & 25.03 & 7.63 & 2.75 & 5.42 & 2.40 & 2.26 & 5.85 \\
\hline G39 & 43.20 & 1.07 & 10 & 25.47 & 110.67 & 93 & 120 & 131 & 29.53 & 9.42 & 3.06 & 6.66 & 2.68 & 2.49 & 24.14 \\
\hline G40 & 31.40 & 0.74 & 16 & 19.40 & 95.67 & 108 & 135 & 62 & 26.40 & 8.01 & 3.20 & 6.22 & 2.76 & 2.26 & 14.95 \\
\hline GM & 38.05 & 1.04 & 11.65 & 23.44 & 94.22 & 116.43 & 142.81 & 122.85 & 21.83 & 8.26 & 2.76 & 5.84 & 2.42 & 2.46 & 20.24 \\
\hline $\mathrm{CV}$ & 4.40 & 6.30 & 10.15 & 5.08 & 4.99 & 3.91 & 3.76 & 4.14 & 4.54 & 5.91 & 6.58 & 5.58 & 4.48 & 6.45 & 9.82 \\
\hline
\end{tabular}

$\mathrm{LL}=$ Leaf length $(\mathrm{cm}), \mathrm{LW}=$ Leaf width $(\mathrm{cm}), \mathrm{NET}=$ Number of effective tiller, $\mathrm{PL}=$ Panicle length $(\mathrm{cm}), \mathrm{PH}=$ Plant height $(\mathrm{cm}), \mathrm{DF}=$ Days to flowering, $\mathrm{DM}=$ Days to maturity, $\mathrm{FG} / \mathrm{P}=$ Filled grain per panicle, $\mathrm{TGW}=1000$ grain weight $(\mathrm{g}), \mathrm{GL}=$ Grain length $(\mathrm{mm}), \mathrm{GB}=$ Grain breadth $(\mathrm{mm}), \mathrm{DGL}=$ Decorticated grain length $(\mathrm{mm}), \mathrm{DGB}=$ Decorticated grain breadth $(\mathrm{mm}), \mathrm{DGLBR}=$ Decorticated grain length breadth ratio, $\mathrm{Y} / \mathrm{H}=$ yield hill-1 $(\mathrm{g}), \mathrm{GM}=$ Grand mean, $\mathrm{CV}=$ Coefficient of variation 
Table 3. Range, phenotypic variance $\left(\mathrm{V}_{\mathrm{p}}\right)$, genotypic variance $\left(\mathrm{V}_{\mathrm{g}}\right)$, genotypic and phenotypic coefficient of variation $\left(\right.$ GCV and PCV), heritability $\left(h^{2} b\right)$, genetic advance (GA), genetic advance in percent of mean (GAMP) of 40 Boro rice germplasm.

\begin{tabular}{lllllllll}
\hline & Range & $\mathrm{Vg}$ & $\mathrm{Vp}$ & $\mathrm{GCV}$ & $\mathrm{PCV}$ & $\mathrm{h}^{2}$ & $\mathrm{GA}$ & $\mathrm{GAM}(\%)$ \\
\hline LL $(\mathrm{cm})$ & $22-72.27$ & 69.21 & 72.01 & 21.86 & 22.30 & 96.12 & 12.89 & 33.87 \\
LW $(\mathrm{cm})$ & $0.65-1.43$ & 0.03 & 0.03 & 15.40 & 16.56 & 86.52 & 0.24 & 22.64 \\
NET & $6.93-24.67$ & 10.06 & 11.46 & 27.23 & 29.06 & 87.81 & 4.70 & 40.32 \\
PL $(\mathrm{cm})$ & $18.27-31.47$ & 8.21 & 8.45 & 12.22 & 12.40 & 94.18 & 4.46 & 19.04 \\
PH (cm) & $63.73-123$ & 185.67 & 193.59 & 14.46 & 14.77 & 95.91 & 21.08 & 22.38 \\
DF & $93-139$ & 84.60 & 85.71 & 7.90 & 7.95 & 96.70 & 14.44 & 12.40 \\
DM & $120-166$ & 77.50 & 78.68 & 6.16 & 6.21 & 95.50 & 13.80 & 9.67 \\
FG/P & $45-204.33$ & 1387.01 & 1412.93 & 30.32 & 30.60 & 95.17 & 47.31 & 36.47 \\
TGW (g) & $10.6-30.72$ & 25.84 & 25.96 & 23.29 & 23.34 & 90.56 & 8.01 & 35.72 \\
GL (mm) & $5.25-9.78$ & 0.89 & 0.91 & 11.41 & 11.57 & 93.27 & 1.47 & 17.79 \\
GB (mm) & $2.07-3.48$ & 0.13 & 0.13 & 12.90 & 13.00 & 93.52 & 0.56 & 20.23 \\
DGL (mm) & $3.55-7.10$ & 0.55 & 0.56 & 12.68 & 12.77 & 92.47 & 1.16 & 19.87 \\
DGB (mm) & $1.83-2.90$ & 0.08 & 0.09 & 11.45 & 12.30 & 86.74 & 0.41 & 16.85 \\
DGLBR & $1.38-3.58$ & 0.25 & 0.25 & 20.22 & 20.51 & 91.17 & 1.78 & 31.49 \\
Y/H (g) & $5.85-26.43$ & 30.43 & 30.56 & 27.25 & 27.31 & 89.55 & 6.70 & 35.96 \\
\hline
\end{tabular}

$\mathrm{LL}=$ Leaf length $(\mathrm{cm}), \mathrm{LW}=$ Leaf width $(\mathrm{cm}), \mathrm{NET}=$ Number of effective tiller, $\mathrm{PL}=$ Panicle length $(\mathrm{cm}), \mathrm{PH}=\mathrm{Plant}$ height $(\mathrm{cm}), \mathrm{DF}=$ Days to flowering, $\mathrm{DM}=$ Days to maturity, $\mathrm{FG} / \mathrm{P}=$ Filled grains per panicle, $\mathrm{TGW}=1000$ grain weight $(\mathrm{g}), \mathrm{GL}=$ Grain length $(\mathrm{mm}), \mathrm{GB}=$ Grain breadth $(\mathrm{mm}), \mathrm{DGL}=$ Decorticated grain length $(\mathrm{mm}), \mathrm{DGB}=$ Decorticated grain breadth $(\mathrm{mm}), \mathrm{DGLBR}=$ Decorticated grain length breadth ratio, $\mathrm{Y} / \mathrm{H}=$ Yield/hill(g), $\mathrm{Vg}=$ Genotypic variance, $\mathrm{Vp}=$ Phenotypic variance, $\mathrm{GCV}=$ Genotypic coefficient of variation, $\mathrm{PCV}=$ Phenotypic coefficient of variation, $\mathrm{h}^{2} \mathrm{~b}=$ heritability, GA= Genetic advance, GAMP= Genetic advance in percent of mean

Heritability estimates (above 60\%) along with genetic advance (above 20\%) would be helpful in predicting gain under selection than heritability estimates alone. In this study, the estimation of genetic advance in the percent of mean were very high for number of effective tiller (40.32), filled grain per panicle (36.47), TGW (35.72), yield hill-1 (35.96) and whereas moderate for, leaf length (33.87) and decorticated grain length- breadth ratio (31.49). Similar results were reported by Mishra and Verma (2002) and Bornare et al. (2014). The characters, which exhibited high heritability, suggests that the selection will be more effective whereas the traits showing low heritability indicates that the selection will be influenced by the environmental factors. These results matched with Islam et al. (2016) and Lakshmi et al. (2017).

Table 4 presents the genotypic and phenotypic correlations of coefficient among the traits. The results revealed that genotypic correlations of coefficient values are always higher than the phenotypic correlations of coefficient value. Leaf length, days to flowering, days to maturity and TGW showed highly positive significant correlation present with yield hill-1 and these results agreed with Devi et al. (2017), Naseer et al. (2015), Vanisree et al. (2013) and Gour et al. (2017). Panicle length showed positive significant correlation with yield. In this circumstance, these traits would be effective in the direct selection process and meets with the findings of Reddy et al. (2013). Number of effective tiller showed significant negative correlation with yield so that this trait must be discarded from the direct selection. Similarly, plant height and decorticated grain length breadth ratio showed non-significant negative correlation with yield and matched with Moosavi et al. (2015) and Rawte and Saxena (2017). On the other hand, filled grain per panicle, grain length, grain breadth, decorticated grain length and decorticated grain breadth showed positive non-significant correlation with yield. Therefore, direct selection based on these traits would not be effective. 
Leaf length, leaf width, days to flowering and TGW showed positive direct effect on yield and made the total correlation positive and significant (Table 5). Similar results were observed by Ashok et al. (2016) and Chuchert et al. (2016). Therefore, direct selection based on these traits would be effective for the yield improvement of Boro germplasm. Days to maturity projected negative direct effect on yield but made the total correlation positive and highly significant. Therefore, direct selection based on days to maturity would not hamper the yield improvement. Number of effective tiller showed negative direct effect on yield and made the total correlation negative and significant. This finding was in accordance with Prasad et al. (2013). Therefore, this trait has no effect on further yield improvement strategy of the studied germplasm. However, panicle length, grain length and grain breadth had negative direct effect on yield but made the total correlation positive and non-significant. This result agreed with Ketan and Sarkar (2014). Filled grain per panicle, decorticated grain length and decorticated grain breadth showed positive direct effect on yield and made the total correlation positive non-significant. Therefore, direct selection based on these traits would not hamper the yield improvement. Plant height and decorticated grain length- breadth ratio showed negative direct effect on yield along with negative nonsignificant total correlation which is agreed with Chuchert et al. (2016) and Reddy et al. (2013). Therefore, these traits must be discarded. Besides, the residual effect was found 0.3594 , indicating $64.06 \%$ variability was estimated by the studied 14 yield contributing traits. The rest amount of variability $(35.94 \%)$ would be controlled by other yield contributing traits which were not included in this study.

Table 4. Genotypic correlation coefficient $\left(r_{\mathrm{g}}\right)$ and phenotypic correlation coefficient $\left(\mathrm{r}_{\mathrm{p}}\right)$ of 40 Boro rice germplasm.

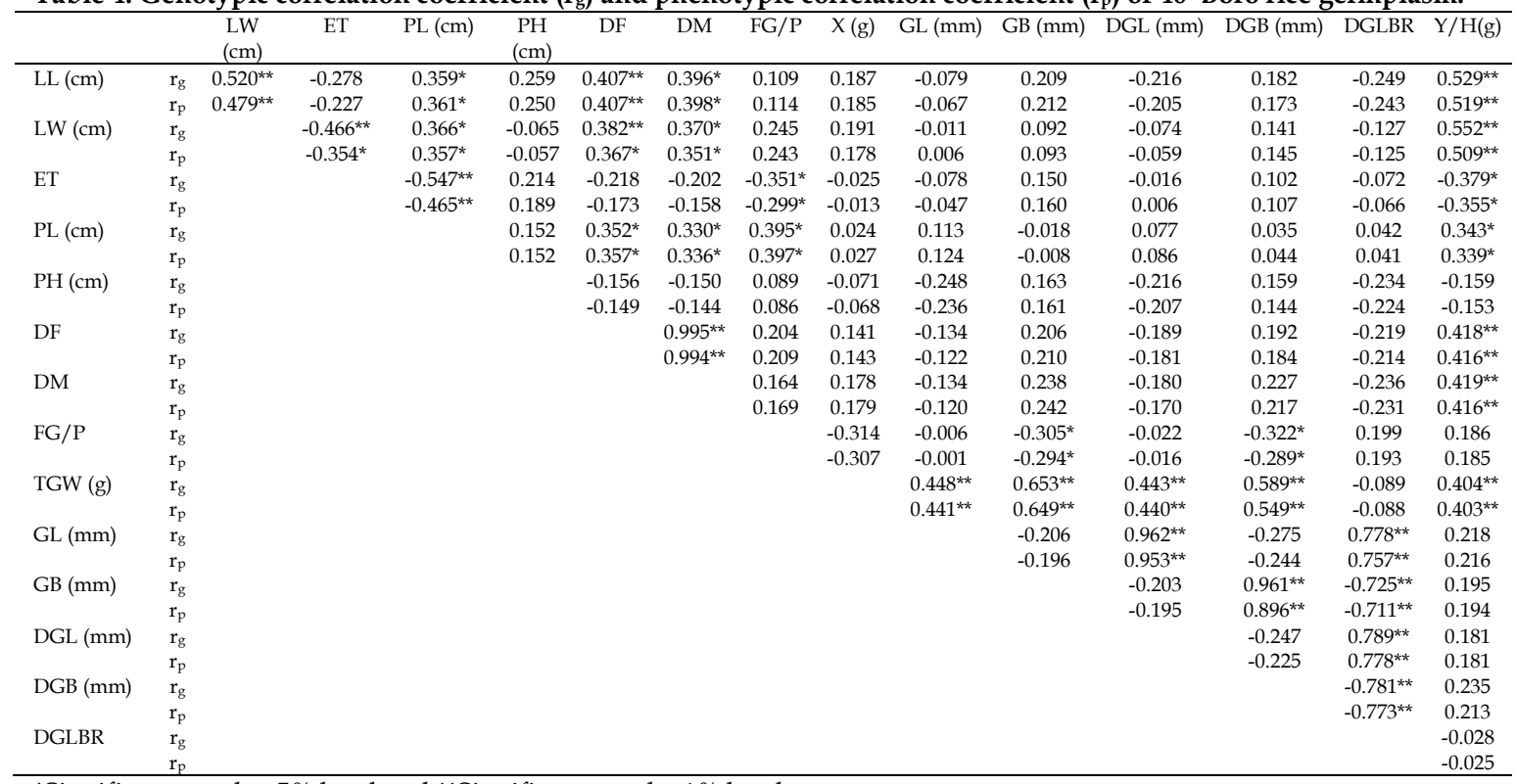

\footnotetext{
*Significance at the $5 \%$ level and **Significance at the $1 \%$ level.
}

LL= Leaf length $(\mathrm{cm}), \mathrm{LW}=$ Leaf width $(\mathrm{cm}), \mathrm{NET}=$ Number of effective tiller, $\mathrm{PL}=$ Panicle length $(\mathrm{cm}), \mathrm{PH}=\mathrm{Plant}$ height (cm), DF= Days to flowering, DM= Days to maturity, FG/P= Filled grains per panicle, TGW=1000 grain weight (g), GL= Grain length $(\mathrm{mm}), \mathrm{GB}=$ Grain breadth $(\mathrm{mm}), \mathrm{DGL}=$ Decorticated grain length $(\mathrm{mm})$, DGB= Decorticated grain breadth $(\mathrm{mm}), \mathrm{DGLBR}=$ Decorticated grain length breadth ratio, $\mathrm{Y} / \mathrm{H}=$ Yield hill $^{-1}(\mathrm{~g})$ 
Table 5. Partitioning of genotypic correlation into direct (bold phase) and indirect components of 40 Boro rice germplasm.

\begin{tabular}{|c|c|c|c|c|c|c|c|c|c|c|c|c|c|c|c|}
\hline & LL $(\mathrm{cm})$ & LW $(\mathrm{cm})$ & NET & P L (cm) & $\mathrm{PH}(\mathrm{cm})$ & $\mathrm{DF}$ & DM & FG/P & $X(g)$ & GL (mm) & GB (mm) & DGL (mm) & DGB (mm) & DGLBR & $\mathrm{Y} / \mathrm{H}(\mathrm{g})$ \\
\hline $\mathrm{LW}(\mathrm{cm})$ & 0.2658 & 0.1291 & 0.0471 & -0.0165 & 0.0196 & 0.1109 & -0.0599 & 0.0460 & 0.0291 & 031 & -0.0350 & -0.0859 & 0107 & 0.0874 & $0.5515^{* *}$ \\
\hline ET & -0.1368 & -0.0549 & -0.0873 & 0.0237 & -0.0464 & -0.0595 & 0.0307 & -0.0627 & -0.0032 & 0.0389 & -0.0584 & -0.0196 & 0.0077 & 0.0480 & $-0.3798^{*}$ \\
\hline $\mathrm{PL}(\mathrm{cm})$ & 0.1890 & 0.0468 & 0.0452 & -0.0457 & -0.0343 & 0.1042 & -0.0548 & 0.0745 & 0.0039 & -0.0673 & 0.0055 & 1015 & 0.0028 & -0.0287 & 0.3426 \\
\hline DF & 0.2138 & 0.0485 & 0.0176 & -0.0161 & 0.0348 & 0.2947 & -0.1639 & 0.0387 & 0.0222 & 0.0749 & -0.0789 & -0.2337 & .0142 & 1515 & $0.4183^{* *}$ \\
\hline DM & 0.2085 & 0.0469 & 0.0163 & -0.0152 & 0.0335 & 0.2931 & -0.1648 & 0.0312 & 0.0279 & & 0.0911 & 2220 & 0177 & 1619 & $0.4185^{* *}$ \\
\hline FG/P & 582 & 0.0315 & 0.0290 & -0.0181 & -0.0200 & 0.0606 & -0.0273 & 0.1884 & -0.0488 & 0.0026 & & 249 & -0.0233 & -0.1365 & 0.1861 \\
\hline TGW (g) & 0.0987 & 0.0240 & 0.0017 & -0.0011 & 0.0157 & 0.0418 & -0.0293 & -0.0586 & 0.1568 & -0.2573 & -0.2481 & .5552 & 0.0433 & 0.0615 & $0.4043^{* *}$ \\
\hline DGL & 1114 & -0.0088 & 0.0007 & -0.0036 & & -0.0548 & 0.0291 & -0.0037 & 0.0693 & -0 . & 0.0763 & 62 & -0.0181 & -0.5443 & 0.1813 \\
\hline DGB (mm) & 0.0941 & 0.0184 & -0.0098 & -0.0017 & -0.0347 & 0.0658 & -0.0367 & -0.0584 & 0.0902 & 0.1525 & -0.3578 & -0.3005 & 0.0753 & 0.5387 & 0.2354 \\
\hline DGLBR & -0.1299 & -0.0163 & 0.0064 & -0.0018 & 0.0522 & -0.0639 & 0.0385 & 0.0371 & -0.0145 & -0.4453 & 0.2741 & 0.9873 & -0.0596 & -0.6926 & -0.0283 \\
\hline
\end{tabular}

Residual Effect= 0.3594. LL= Leaf length $(\mathrm{cm}), \mathrm{LW}=$ Leaf width $(\mathrm{cm}), \mathrm{NET}=$ Number of effective tiller, $\mathrm{PL}=$ Panicle length $(\mathrm{cm}), \mathrm{PH}=$ Plant height $(\mathrm{cm}), \mathrm{DF}=$ Days to flowering, $\mathrm{DM}=$ Days to maturity, FG/P= Filled grain per panicle, TGW=1000 grain weight $(\mathrm{g}), \mathrm{GL}=$ Grain length $(\mathrm{mm}), \mathrm{GB}=$ Grain breadth $(\mathrm{mm}), \mathrm{DGL}=$ Decorticated grain length (mm), DGB= Decorticated grain breadth $(\mathrm{mm}), \mathrm{DGLBR}=$ Decorticated grain length breadth ratio, $\mathrm{Y} / \mathrm{H}=\mathrm{Yield}^{\mathrm{e}}$ hill-1 $(\mathrm{g})$

\section{CONCLUSIONS}

Presence of genetic variability is an utmost requirement for the improvement of economically important traits like yield in rice. Boro rice germplasm possessed adequate amounts of variability for yield and its associated traits. High heritability coupled with high genetic advance as percent of mean was observed in leaf length, number of effective tiller, filled grains panicle ${ }^{-1}$, TGW and decorticated grain length- breadth ratio. Finally, it can be concluded that the G28, G20, G11, G17 and G2 are the elite germplasm and these germplasm can directly be selected for the future yield improvement on the basis of yield and other major yield contributing characters. Moreover, G39 (Unknown-2) can be used as early maturing Boro rice germplasm along with its higher grain yield in future breeding programme.

\section{ACKNOWLEDGEMENTS}

The authors are grateful to the project on 'Collection, characterization and promotion of rice, chilli, cucumber and melon in Bangladesh' supported by AFACI (Asian Food and Agriculture Cooperation Initiative) for providing fund for this research.

\section{REFERENCES}

Ahmed, M S, S Parveen, M K Bashar and A K M Shamsuddin. 2015. Genetic divergence of Balam rice (Oryza sativa L.) germplasm of Bangladesh. Bangladesh Rice J. 19 (1): 9-14.

Akter, N, M Khalequzzaman, M Z Islam, M A A Mamun and M A Z Chowdhury. 2018. Genetic variability and character association of quantitative traits in jhum rice genotypes. SAARC J. Agri. 16 (1): 193-203. DOI: http://dx.doi.org/10.3329/sja.v16i1.37434.

Anonymous. 2017. Statistical Yearbook of Bangladesh. Bangladesh Bureau of Statistics. Ministry of Planning, Govt. of the People's Republic of Bangladesh. Dhaka, Bangladesh. p. 49- 92.

Ashok, S, D P B Jyothula and D Ratnababu. 2016. Character association and path analysis for yield components and grain quality parameters of rice (Oryza sativa L.). Int. J. Agril. Sci. and Res. 6 (6): 253-258.

BBS. 2017. Year book of agricultural statistics 2017. 27thed. Bangladesh Bureau of Statistics, Statistics and Informatics Division, Ministry of Planning, Gov. of the People's Republic of Bangladesh. Dhaka, Bangladesh. www.bbs.gov.bd.

Bornare, S S, S K Mittra and A K Mehta. 2014. Genetic variability, correlation and path analysis of floral, yield and its component traits in CMS and restorer lines of rice (Oryza sativa L.). Bangladesh J. Bot. 43 (1): 45-52.

Burton, G W. 1952. Proceedings of Intercropping Grassland Congress: Quantities inheritance in grasses. 1 (6): 277-283.

Chuchert, S, C Nualsri, N Junsawang and W Soonsuwon. 2016. Genetic diversity, genetic variability, and path analysis for yield and its components in indigenous upland rice (Oryza sativa L. var. 
glutinosa). Songklanakarin J. Sci. and Tech. 0323: 1-23.

Comstock, R E and H F Robinson. 1952. Estimation of average dominance of genes. In: J H Gowen (ed.), Heterosis, Iowa State College Press, USA. Pp. 494-516.

Devi, K R, B S Chandra, N Lingaiah, Y Hari and V Venkanna. 2017. Analysis of variability, correlation and path coefficient studies for yield and quality traits in rice (Oryza sativa L.). Agril. Sci. Digest. 37 (1): 1-9.

Dewey, D R and K H Lu. 1959. A correlation and path coefficient analysis of components of crested wheat grass seed production. Agronomy J. 51 (9): 515-518.

Falconer, D S. 1964. An Introduction to Quantitative Genetics. In: Oliver and Boyd (2nd ed.), Edinburgh. Pp. 312-324.

Gour, L, G K Koutu, S K Singh, D D Patel, A Shrivastava and Y Singh. 2017. Genetic variability, correlation and path analyses forselection in elite breeding materials of rice (Oryza sativa L.) genotypes in Madhya Pradesh. The Pharma Innovation J. 6(11): 693-696.

HIES. 2010. Household Income and Expenditure Survey, Bangladesh Bureau of Statistics, Ministry of Planning, Government of the People's Republic of Bangladesh, Dhaka.

Islam, M Z, M Khalequzzaman, M A Siddique, N Akter, M S Ahmed and M A Z Chowdhury. 2017. Phenotypic Characterization of Jhum Rice (Oryza sativa L.) Landraces Collected from Rangamati District in Bangladesh. Bangladesh Rice J. 21 (1): 47-57.

Islam, M Z, M Khalequzzaman, M K Bashar, N A Ivy, M M Haque and M A K Mian. 2016. Variability assessment of aromatic and fine rice germplasm in Bangladesh based on quantitative traits. 2016: 1-14. The Sci. World J. http:/ /dx.doi.org/10.1155/2016/2796720.

Islam, M Z, M Khalequzzaman, M F R K Prince, M A Siddique, E S M H Rashid, M S U Ahmed, B R Pittendrigh and M P Ali. 2018. Diversity and population structure of red rice germplasm in Bangladesh. PLoS ONE 13 (5): e0196096. https:// doi.org/10.1371/journal.pone.0196096

Johnson, H W, H F Robinson and R E Comstock. 1955. Estimates of genetic and implications in selection. Agronomy J. 50: 126-131.

Ketan, R and G Sarkar. 2014. Studies on variability, heritability, genetic advance and path analysis in some indigenous Aman rice (Oryza sativa L.). J. Crop and Weed. 10 (2): 308-315.

Khatun, M T, M M Hanafi, M R Yusop, M Y Wong, F M Salleh and J Ferdous. 2015. Genetic variation, Phenotypic Characterization of Jhum Rice Landraces 57 heritability and diversity analysis of upland rice (Oryza sativa L.) genotypes based on quantitative traits. Bio Med Res. Int, Article ID 290861.

Lakshmi, L, M V B Rao, C S Raju and S N Reddy. 2017. Variability, Correlation and Path Analysis in Advanced Generation of Aromatic Rice. Int. J. Curr. Microbiol. App. Sci. 6 (7): 1798-1806. https:// doi.org/10.20546/ijcmas.2017.607.217

Lush, J L. 1949. Heritability of quantitative characters in farm animals. Heriditas. 35: 256-261.

Mishra, L K and R K Verma. 2002. Genetic variability for quality and yield traits in non segregating populations of rice (Oryza sativa L.). Plant Archives. 2 (2): 251-256.

Moosavi, M, G Ranjbar, H N Zarrini and A Gilani. 2015. Correlation between morphological and physiological traits and path analysis of grain yield in rice genotypes under Khuzestan conditions. Biological Forum 7 (1): 43-47.

Naseer, S, M Kashif, H M Ahmad, M S Iqbal and Q Ali. 2015. Estimation of genetic association among yield contributing traits in aromatic and nonaromatic rice (Oryza sativa L.) cultivars. Life Sci. J. 12 (4): 68-73

Nirmaladevi G, G Padmavathi, S Kota and V R Babu. 2015. Genetic variability, heritability and correlation coefficients of grain quality characters in rice (Oryza sativa L.). SABRAO J. Breed. Genet. 47 (4): 424-433.

Prasad, G S, M Sujatha, L V S Rao, U Chaitanya and P Patroti. 2013. Character Association and Path Analysis in Rice (Oryza sativa L.) Genotypes for cold tolerance. Helix. 3: 349-352.

Rawte, S and R R Saxena. 2017. Correlation and path coefficient analysis of quality traits in selected rice (Oryza sativa L.) germplasm accessions.

International Journal of Chemical Studies. 5 (5): 547-551.

Reddy, G E, B G Suresh and T Sravan. 2013. Correlation and path analysis for yield and yield attributes in rice (Oryza sativa L.) genotypes. Int. J. Plant Sci. 8 (2): 391-394.

Singh, S K, C M Singh and G M Lal. 2011. Assessment of genetic variability for yield and its component characters in rice (Oryza sativa L.). Research in Plant Biology. 1 (4): 73-76.

Singh, R K and B D Choudhury. 1985. Biometrical methods in quantitative genetic analysis. Kalyani Publishers, New Delhi, pp: 102-138.

Singh, R K, P L Gautam, S Sanjcev and S Singh. 2000. Scented Rice Germplasm: Conservation, evaluation and Utilization. In: Aromatic rices (Singh, R K, Singh, U S, Khush, G S Eds.). Oxford and IBS publishing Co. Ltd., New Delhi, India. Pp. 107-134.

Vanisree, S, K Swapna, C D Raju, C S Raju and M Sreedhar. 2013. Genetic variability and selection criteria in rice. J. Biological and Scientific Opinion. 1 (4): 341-346. 
